\title{
1742-1754 Yıllarında Vergi Tahsilatındaki Usulsüzlüklere Dair Bazı Tespit, Teşhis ve Tahliller: Diyarbakır Vilayeti Örneği
}

\author{
İBRAHIM ÖZGÜL* \\ ibrahimozgul61@mynet.com \\ ORCID ID: 0000-0002-5325-8326
}

Öz: Bu çalışmada Diyarbakır vilayetinde 1742-1754 yılları arasında vergi tahsilatı sırasında vuku bulan usulsüzlüklerin tespit edilerek ortaya konulması amaçlanmıştır. Araştırmada Diyarbakır Ahkâm defterleri ile bu konudaki diğer kaynaklardan istifade edilerek durum tespiti yapılmıştır. Çalışmadan elde edilen bulgulara göre Osmanlı Devlet anlayışında kanun riayeti, kanunların uygulanışı, halkın karşılaştığı haksızlıkları üst mercilere ve idareye karşı dava açma hakkı olan reayanın rahatlıkla şikâyetlerde bulunabildiği görülmüştür. Ayrıca yetkililerin ise şikâyetleri kanun, adalet ve ahlak prensipleri bağlamında icra etme zorunda oldukları ve bu konularda sık sık adaletnameler ve fermanlar yayımlandiğı tespit edilmiştir. Vergi sistemini ayrıntılı bir şekilde kayıt altına alarak bu doğrultuda iş ve işlemler sağlıklı bir şekilde yürütülmeye çalışılmıştır. Vergi tahsilatı sırasında görevlilerin fazla vergi alma yoluna gitmeleri gibi uygulamalara da rastlanıldı̆̆ı sonucuna ulaşılmıştır.

Anahtar kelimeler: Diyarbakır, Ahkâm defterleri, Vergi, XVIII. yüzyıl.

\section{Giriş}

Diyarbakır, Irak ve İran’ı Akdeniz ve Karadeniz’e bağlayan yolların kavşağında kurulmuştur. M.Ö 2300'den beri yerleşim merkezi olan bu şehir, devamlı olarak cazibe merkezi olduğunda birçok devlet arasında el değiştirmiştir. 23 Ağustos 1514 tarihinde Çaldıran Savaşında Safevilerin yenilmesi, Tarihçi İdris-i Bitlisỉnin bölgedeki girişimleri sonucu Sünni beylik ve aşiretlerin Osmanlı Devleti’nin idaresini kabul etmeleriyle Diyarbakır halkı Safevi idaresine karşı ayaklanarak Safevi yönetimine son verip Osmanlı Sultanı Yavuz Sultan Selime biatini bildirerek Osmanlı idaresine katıldı. Osmanlı idaresine girdikten sonra Amid merkez olmak üzere Diyarbakır Beylerbeyliği kuruldu. Osmanlı yönetimi sırasında bu Beylerbeyliğinin sınırları, bağlı sancak, kaza, köy ve mezra sayılarında meydana gelen gelişmelere bağlı olarak

\footnotetext{
*Ağrı İbrahim Çeçen Üniversitesi, Eğitim Fakültesi, Sosyal Bilgiler Eğitimi Anabilim Dalı.
} 
değişim geçirmiştir. ${ }^{1}$

Diyarbakır Osmanlı hâkimiyetine girdikten sonra 1518 yılında yapılan tahrire göre Diyarbakır Beylerbeyliğine bağlı on iki sancak vardı. Bunlar: Amid, Mardin, Sincar, Berriyecik, Ruha, Siverek, Çermik, Ergani, Harput, Arapkir, Kiğı, ve Çemişkezek’ten oluşuyordu. Kısa bir süre sonra Amid ve Mardin birleştirilmiş Berriyecik bir kaza olarak Mardin sancağına bağlanmış, Musul Deyrirahbe, Anê, ve Hit sancakları da bağlanarak sayı on dörde çıkmıştı. Yurtluk ve ocaklık sistemiyle idare edilen Atak, Palu, Çapakçur, Sasun, tercil, Kulp, Bitlis, Cizre, Genç, Cüngüş, Hisnıkeyfâ gibi birimlerde Beylerbeyliğe bağlıydı. Bağdat'ın fethinden sonra Âne, Hit ve Musul Sancakları Bağdat Beylerbeyliğine bağlanırken, Bitlis XVI. yy’n sonunda Van Beylerbeyliğine bağlanmıştır. Urfa ise bazen Rakka Beylerbeyliğine bazen de Diyarbakır Beylerbeyliğine bağlanmıştır. ${ }^{2}$

Tanzimat döneminde yapılan düzenlemeler sonucu çıkarılan 7 Kasım 1864 vilayet nizamnamesi ve buna bağlı idari alanda yapılan değişiklikler gereğince eyalet sisteminden vilayet, kaza, nahiye, köy düzeyinde yapılandırılan idari sisteme geçilmiştir. $\mathrm{Bu}$ sisteme geçmekle bazı birimlerin diğer vilayetlere bağlandığı gibi doğu ve güneydoğu Anadolu bölgesindeki Kürt beylerine ayrılan has, zeamet ve tımar halka dağıtılarak liva sancak beyleri maaşa bağlandı. Böylece yurtluk ve ocaklık sisteminde mutasarrıf olan beyler yerinde kalarak ve merkezden bir atama yapılmayarak maaşa bağlanmış oldu. ${ }^{3}$

$\mathrm{Bu}$ çalışmamızın amacı, belirtilen tarih aralığında Diyarbakır Beylerbeyliği sınırları içinde yer alan birimlerde vergi tahsilatında ortaya çıkan usulsüzlükler ve bu konuda yapılan şikâyetlerin sonuçlarıyla birlikte ortaya koymaktır. Bu konuda Diyarbakır Ahkâm defterleri ve diğer kaynaklardan istifade edilerek vergi alanında yapılan usulsüzlüklerle ilgili olarak Osmanlı Devlet anlayışının kanun riayeti, kanunların uygulanışı, halkın karşılaştığı haksızlıkları üst mercilere ve idareye karşı dava hakkı olan reayanın rahatlıkla şikâyetlerde bulunduğu belirtilmeye çalışılmıştır.

Osmanlı Devleti’nin vergi gelirlerini teşkil eden esas unsur tarımdan elde edilen vergilerdir. Devletin tarımdan aldığı vergiler, devlet gelirlerinin önemli bir kısmını oluşturmaktaydı. Bunun yanında ticaret ve zanaat faaliyetlerinden elde edilen gelir ikinci sırada kalmaktaydı. Bu nedenle Osmanlı Devleti, ayrıntılı ve hayli gelişmiş bir zirai hukuka sahipti. Diğer taraftan bu vergilerin tayin ve tespiti yine gelişmiş ve karmaşık mali usullerin varlığını gerekli kılıyordu. Osmanlı maliyesindeki karışık ve yüzlerce vergi ismi gösteren yüzlerce cetvelin sağlam kaidelere dayandırılması suretiyle karmaşıklık giderilmiştir. Osmanlı vergi alma usulleri dört başlık altında toplanmaktadır. Birincisi şer’î vergiler (İslami vergi esaslarına göre alınan vergiler), ikincisi örfî vergiler, üçüncüsü harp giderlerini karşılamak üzere Avarız-1 Divaniye yahut Tekâlif-i Divaniye vergileri, dördüncüsü her türlü kanun ve nizam dişı olmakla

1 Türkiye Diyanet Vakfı İslam Ansiklopedisi, Nejat Göyünç, İstanbul, 1994, “Diyarbakır” maddesi.

2 Türkiye Diyanet Vakfı İslam Ansiklopedisi, "Diyarbakır” maddesi.

3Abdullah Demir, "XVIII-XIX. Yüzyıllarda Çapakçur Sancağı ve İdari Yapısı”, Arşiv Vesikalarına Göre Bingöl Kolokyumu, Ankara: Bingöl Belediyesi Yayınları, 2011. 
birlikte yöneticilere verilen hediyelerdir. ${ }^{4}$

$\mathrm{Bu}$ geleneksel tarımın ve verginin baş aktörü kuşkusuz evlenmiş çoluk çocuk sahibi olmuş erkek köylünün simgelediği köylü aile yapısıdır. Devlet vergi mükellefi olarak onu tanır. Bunun sonucu olarak da mirî toprak rejimi, devlete bütün köylü sınıfını ve tarım ekonomisini kontrol ve düzenleme yetkisi veriyordu. (Her şeyden evvel toprağın sahibi baştaki sultanın şahsiyetinde temsil ettiği devletti ve köylüler sadece toprağın kullanım hakkına yani rakabesine sahipti). Çünkü büyük kitlelerin geçimi, ekonominin temeli, ordunun ve şehirlerin iaşesi, mirî arazide üzerinde yapılan tarıma dayanıyordu. Köylü tarımsal faaliyetini ifa ederken bir taraftan devletin belirlediği vergileri veriyor, diğer taraftan da devlete ve sipahiye kanunların emrettiği bedeni hizmetleri sunuyordu. Ancak devletin belirlediği bu hizmetler dışında karşılıksız hiçbir bedeni hizmet yapmağa mecbur değildi.

$\mathrm{Bu}$ süreçlerde devlet görevlileri ile reaya arasında ortaya çıkan ihtilafları gidermek ve bir nevi denge unsuru olarak görev yapmak ise yine devlet tarafından atanan kadılara düşüyordu. Her kazada kadının hükmü altında 40-50, bazen de 300 kadar köyü toplamaktadır. Bu köylerde ortaya çıan hukuki sorunlar, o şehir veya kasaba kadısının mahkemesine gelir. Köy davaları için çoğu zaman nâib atadığı da oluyordu. ${ }^{5}$

Osmanlı Devleti, dayandığı adalet kavramından dolayı halkın şikâyetlerini doğrudan doğruya hükümdara sunabilmesi imkânı verildiğinden Divan-1 Hümayuna yapılan başvurular Padişaha yapılmış kabul ediliyordu. Padişah’ta direk halktan şikâyet aldığı da oluyordu. Bu nedenle yapılan şikâyetler dikkatli bir şekilde değerlendirilirdi. Şikâyetler, mutlaka bir zararını veya uğradığı bir haksızlığı gidermek için zarar gören taraf, bir şahıs, bir grup veya bir kurum da olabilir. Çalışmamızın konusunu teşkil eden halkın, kanuna aykııı alınan vergilerden şikâyetleri içermektedir. Reayadan kişilerle resmi görevliler arasındaki sorunlar padişaha "arz-1 hal" göndererek hükümler istenmekteydi. Padişah, merkezde verilecek hükümler yanlış olabilir endişesiyle konun mahallinde ve mahiyetine göre Kadi'ya veya "örfi”" idare adamına hitap eder. Konu her ikisini de ilgilendiriyorsa ikisine de gönderilirdi. ${ }^{6}$

Halka ağır gelen angaryalar, halka salınan olağan üstü nakdi ve ayni vergiler, idarecilerin kendi adlarına zorla para ve mal toplamaları ile ehl-i örf adı verilen beylerbeyleri, sancakbeyleri, tımarlı sipahiler, şehir ve kasabalarda yerleşmiş kapıkulu mensuplarının zor kullanarak halka yaptıkları zulümleri önlemek ve cezalandırmak için de adaletnameler gönderilmiştir. Kanunların usulsüz uygulanışını önlemek için çıkarılmış genel fermanlar olarak Osmanlı hukuk anlayışını uygulaması bakımından önemli fonksiyonları olmuştur. ${ }^{7}$

Osmanlıda hükümler bizzat padişah tarafından verilmez, Padişahı̉ı yetki verdiği makam veya bu makama bağlı daireler onun adına hüküm verebilirlerdi. Bu bakım-

4 Mustafa Akdağ, Türkiye’nin İktisadî ve İçtimaî Tarihi-I, Ankara: Barış Kitap Basım Yayın Dağıtım, 1999, Ankara, s.405-407.

5 Halil İnalcık, Osmanl İmparatorluğu Toplum ve Ekonomi, İstanbul: Eren Yayınları, 1996, s.4-9.

6 Halil İnalcık, Osmanlida Devlet, Hukuk, Adalet, İstanbul: Eren Yayıncılık, 2005, s.49-55.

7 Türkiye Diyanet Vakfı İslam Ansiklopedisi, Halil İnalcık, İstanbul, 1988, “Adaletnâme” maddesi. 
dan hükümler sadaret makamından veya defterdarlıktan çıkardı. Sadaret makamından çıkan hükümler ferman adını alarak suretleri mühimmelerde toplanırdı. Defterdarlıktan çıkan ahkâmın toplandığı defterlere ise ahkâm-ı maliye denirdi. ${ }^{8}$

Osmanlı Devletinde askeri sınıf, saray halkı, seyfiye (ehl-i seyf, ehl-i örf de denilen askeri hizmetleri yerine getiren ulufe ve tımar alan bütün hizmet sahipleri), kalemiye (kamu hizmetini gören bürokrasi) ve ilmiye ( ehli şerde denilen ulema, kadı müderris, imam, müezzin, camii görevlileri ve Peygamber efendimizin soyundan gelen Seyyid ve Şerifler, şeyhler, yargı, ilim ve din görevlileri) vergi muafiyetinden yararlanıyorlardı. Bu grupların eşleri, çocukları, köle ve cariyeleri ile emekli olanları da askeri sinıftan sayıliyorlardı. ${ }^{9}$

\section{Vergiden Muaf Bir Zümre Olarak Seyyidler}

Hz. Muhammed'in ailesi, yakın akrabası ve soyundan gelenler, Müslümanların nazarında müstesna bir mevkie sahip olmuş, bunları sevip saymak dini bir vecibe olarak kabul edilmiştir. Onlarla ilgili bazı hizmetleri görmek üzere görevliler tayin edilmiştir. Böylece zamanla nikabet müessesesi ortaya çımıştır. Bu müessesse Osmanlı Devleti’nde Yıldırım Bayezid döneminde Seyyid ve Şeriflerle ilgilenmek üzere ihdas edildiği ve bu makama da Seyyid Muhammed Nattâ Hüseyin getirilmiştir. $\mathrm{Bu}$ kurumun kurumsallaşması II. Bayezid döneminde daha da oturarak Seyyid ve şeriflerin şeceresini kaydederek Seyyid olmayanların Seyyidlere sağlanan imkân ve imtiyazlardan yararlanmasi engellenmekteydi. ${ }^{10}$

Selçuklularda görülen Seyyidlere sağlanan vergi muafiyetleri, Osmanlı Devletỉnin kuruluşunun ilk yıllarında uygulanarak ülkeye şeyhler, âlimler ve Seyyidlerin gelmesini sağllyordu. Bu konuyla ilgili olarak I. Murad döneminde bir şikâyet üzerine H.787/ M.1385 tarihinde Seyyidler için verdiği vergi muafiyeti beratı verilmiştir. Bu berata göre Seyyidlerden öşür alınmadığı gibi, Koyun hakkından (Resm-i Ağnam) muaf olduklarını gösterir. Beratın sonunda, bu hükmü değiștirenlere ins ve cin lanet etsin bedduası bu uygulamanın devamını da sağlamıştır. ${ }^{11}$

Seyyidler'in hüccetlerinde rüsum-i örfiye, devletin tebaasından, şer’î hükümler dışında örften aldığı vergilerin tamamına verilen isimdir. Tekâlif-i örfiye ve Avarız-1 Divaniye-1 divaniyye denilen vergi çeşitlerini de içine alır. Tekâlif-i örfiye vergileri: bu ad altında toplanan vergilerin miktarı, eyaletlere göre değişirdi. Her eyaletin Tapu Tahrir Defterlerinin başında yer alırdı. Bu vergilerin başlıca çeşitleri şunlardı: Mücerret, Bennak, İspence, Arûsiye, Cürüm ve Cinayet, İhtisap, çift bozan tapu, kovan, ağıl, yaylak ve kışlak, Yaya ve Kaçkun, Gümrük. vb. vergileri içermektedir. Avarız-1 Divaniye-1 Divaniye vergisi, olağan üstü hallerde riayette yüklenen mali, ayni ve bedeni vergilerdir. XVI. yüzyıldan itibaren adı geçen vergiler belli miktar para vermeğe

8 Türkiye Diyanet Vakfı İslam Ansiklopedisi, Halil Sahillioğlu, İstanbul, 1988, "Ahkâm Defteri” maddesi. 9 Sadık Müfit Bilge, "XV-XVIII Yüzyıllarda Osmanlı Devletinde Vergi Muafiyeti”" (Osmanlı Coğrafyası Kültürel Arşiv Mirasının Yönetimi ve Tapu Arşivlerinin Rolü Uluslararası Kongresinde Sunulan Bildiri, İstanbul, 2012.) 10 Türkiye Diyanet Vakfı İslam Ansiklopedisi, Şit Tufan Buzpınar, İstanbul, 2006, "Nakibüleşraf" maddesi.

11 Murat Sarıcık, Osmanlı İmparatorluğginda Nakîbü'l-Eşrâfllk Müessesesi, Ankara: Türk Tarih Kurumu Yayınları, 2003, s.86-87. 
dönüşmüş ve buna avarız akçesi denilmeğe başlanmıştır. Seyyidlere sağlanan muafiyetlerin yanı sıra maaş da bağlandığı olmuştur. Bunun sebebi ise Hz. Muhammed'in zekât almamasından kaynaklanmaktadır. Zekât almayan bu şahıslara ayetler mucibince ganimet ve feyden bește birin beşte biri ayrıliyordu. ${ }^{12}$

Osmanlı Devleti’nin her tarafına dağılan ve her kademede bulunan Seyyidlerin hepsinin şecere veya silsilename adını verdikleri bir nesep imtiyaz belgesine sahip oldukları gibi Seyyidlerin vergiden muafiyetleri ilgili vergi kanunlarında da belirtilir. ${ }^{13}$ Muaf oldukları vergilerden vergi ödemeleri hususunda zorlanan Seyyidlerle ilgili Evail-i Recep 1155/ 2-11 Eylül 1742 tarihli kayıtta, ilgililere gönderilen emirde Mardin'in Şeyzoli köyünden ikamet eden Seyyid Ali ve diğer bazı Seyyidlere, zorbalı̆̆ huy edinmiş bazı kişilerin bunlara ödemede yükümlü olmadıkları vergileri tahsil etmeleri hususunda baskı yaptıkları tespit edilmiştir. Sâdât-1 kiramdan olan Seyyidlere musallat olan bu zorbaların kanun üzere işlem yapılarak defedilmeleri için emri şerif yazılması asayiş boyutu olduğu kadar Seyyidlere gösterilen ihtimam ve itibar açısında da önemlidir. ${ }^{14}$

Zamanla Osmanlı hiyerarşisinde önemli bir yer edinen Nakibüleşraflık müessesesi, genellikle sâdat ve ilmiye mensuplarından seçilerek oluşuyordu. XVII yüzyılın ortalarına kadar ömür boyu görevde kalmışlar, daha sonra ise çeşitli sebeplerden ötürü görevden ayrılmış ve alınmışlardır. Daha önceleri kadı, kazasker veya şeyhülislamlar iki görevi birden de yürütenler vardı. Nakibüleşraflar görevlerini genellikle ikametgâhlarında yerine getirirlerdi. II. Abdülhamid döneminde Yıldız Sarayı semtinde ayrı bir mekân tahsis edilmişti. Hükümetle yapacağı yazışmaları direk sadrazamla yapardı. Nakibüleşraftan sonra en yetkili kişi alemdar, diğer mensuplarına çavuş denirdi. Bu makamın en görevlerinden biri de Seyyid ve Şeriflerin şeceresini kaydederek, sızmaları önlemek ve başkalarının bu imkânlardan faydalanmasını engellemekti. ${ }^{15}$

Evlad-1 Seyyid olanlardan kanun dışı vergi talebinde bulunan görevliler hakkındaki iddialar üzerine yetkililere Evaili Şaban 1155/ 2-11 Ekim 1742 tarihinde gönderilen bir emirde: Diyarbakır’ın İbn Müderris Mahallesi’nde ikamet eden Seyyid Hacı Hüseyin, Seyyid Ramazan, Seyyid İsa, Seyyid Ali, Seyyid Mehmed ve Seyyid Hüseyin'in Mardine bağlı Deyr köyünde ikamet eden Şeyh Zoli Seyyid Musảnın evladından olduklarına dair ellerinde hüccetleri ${ }^{16}$ bulunmaktadır. Bunlar kanunen yükümlü oldukları vergilerini ilgili memurlara ödemişlerdir. Kanuna mugayir tekâlifi örfiye vergisinin talep edildiği ve bunların Seyyid olduklarına itibar etmeyip rencide ettikleri, tespit edilmiştir. Bundan böyle bu tür durumlara meydan verilmemesi ve kanun üzere muamele edilmesi emredildi. Bu durumda kayttların muntazam tutulduğunu

12 Sarıcık, Osmanlı İmparatorluğu’nda Nakîbü’l-Eşrâflık Müessesesi, s. 89-111.

13 Sarıcık, Osmanlı Imparatorluğu’nda Nakîbü’l-Eşrâflık Müessesesi, s. 89-91.

14 Divan-ı Hümayun sicilleri Diyarbekir Ahkâm Defterleri -1- numaralı defter: (H. 1155-1167 / M. 1742-1754),

006-4, ed. Ahmet Zeki İzgöer, Diyarbakır: Dicle Üniversitesi İlahiyat Fakültesi, 2016, s. 16.

15 Türkiye Diyanet Vakfi İslam Ansiklopedisi, "Nakibüleşraf” maddesi.

16 Nikabet Teşkilatının görevlerinden biri, Seyyidliği sabit olanlara hüccet vermek, böylece Seyyid olanla olmayanı ayırmak ve Seyyidlerin başta Tekâlif-i divaniye ve Avarızdan muafiyetlerini sağlayıp, nesebi sabit olmayanlarla ayırmaktı (Sarıcık, 2003: 137). 
ve Sâdâd-1 Kirâma büyük önem verdikleri açıkça görülmektedir. ${ }^{17}$

Sâdâd-1 Kiramdan olan ve ehli örf tarafından kanun dışı vergi talebinde bulunulan görevlilerle ilgili olarak Evahiri Şaban 1155/ 2-11 Ekim 1742 tarihinde emir gönderilmiştir. Bu emirde Diyarbakır’n Mevlana kazasına bağlı Sad kasabasından Seyyidlerden Nakibüleşraf Kaymakamı Seyyid Ali b. Seyyid Abdullah, Kardeşi Seyyid Yahya, Seyyid Abdullah b. Yahya, Amcazade Seyyid Sadeddin ve Seyyid Yusuf'un ödemekle yükümlü oldukları vergilerini eksiksiz ve zamanın da ödedikleri tespit edilmiştir. Bunlardan emri şerife mugayir vergi talep edilerek rencide edilmemeleri ve kanun doğrultusunda amel edilmesi kesin bir dille belirtilmesi, devlet görevlilerinde haksız kazanç elde edilmelerinin önüne geçilmiştir. ${ }^{18}$

Ergani’nin Salih köyü halkının Seyyidlerinde kendileriyle birlikte vergi vermelerinin talep edilmesi üzerine Evasıtı Safer 1156 / 6-15 Nisan 1742 tarihinde gönderilen emirde, anılan köyde ikamet eden Seyyid Mehmed'in sâdâd-1 kiramdan olduğu ve Nakibü’l eşraftan Seyyid olduğuna dair hücceti olduğu, vermekle yükümlü olmadığ 1 vergilerden köylülerin baskısıyla sende bizimle birlikte ver denilerek rencide edilmiştir. Bu konuda Şeyhülislam tarafından verilen fetvaya göre hareket edilmesi ve bir daha bu konuda rahatsı edilmemesi hususunda idarecilerin uyarılması devletin Seyyidlere verdiği değeri de göstermektedir. ${ }^{19}$

Seyyidlerin maişetlerine konu olan gelirlerinin vergiden muaf olmaları için yapılan başvurularda isteklerinin kabul edildiğine dair Evasıtı Safer 1156/ 6-15 Nisan tarihinde gönderilen emirde, Seyyid Ali ve Seyyid Ramazan’ının Mardin kazasına bağlı Serekeci aşiretinden ata babadan Sâdât-1 kiramdan olup, ellerinde İstanbul Nakibü'l eşraftan belgeleri olduğundan, geçimleri için besledikleri yüz ellişer adet koyundan vergi alınmaması için talep edilen emri şerif ve kanun üzere işlem yapılması buyrul$\mathrm{du}^{20}$

Seyyidlerin muaf olduğu vergilerden ve kanunnamelerde geçen vergilerin başında olan Rüsum-i Şeriye muafiyetlerinden biride Âdeti Ağnam veya Resmi Ağnamdır. Kendi maişetleri için yüz elli baş koyuna kadar vergi alınmaması fermanla buyrulmuştu. ${ }^{21}$ Seyidler'in bu konuda bireysel başvuruları da dikkate alınarak bu konuda Evasıt-1 Safer 1156 / 6-15 Nisan tarihinde gönderilen emirde, Mardin kazasının Seyyidlerinden olan Seyyid Ebubekir ile Seyyid Süleyman'ın besledikleri yüz altı koyun için vergi alınmamasını talep etmişlerdir. Bunların sâdâd-ı kiramdan oldukları, Nakibü’l eşraftan hüccetlerinin olduğundan geçimleri için besledikleri bu koyunlardan vergi alınmaması bildirilmiştir. ${ }^{22}$

17Divan-ı Hümayun sicilleri Diyarbekir Ahkâm Defterleri -1- numaralı defter: (H. 1155-1167 / M. 1742-1754), 009-2, ed. Ahmet Zeki İzgöer, Diyarbakır: Dicle Üniversitesi İlahiyat Fakültesi, 2016, s. 23.

18 Divan-ı Hümayun sicilleri Diyarbekir Ahkâm Defterleri -1- numaralı defter: (H. 1155-1167 / M. 1742-1754), 011-4, ed. Ahmet Zeki İzgöer, Diyarbakır: Dicle Üniversitesi İlahiyat Fakültesi, 2016, s. 29.

19 Divan-ı Hümayun sicilleri Diyarbekir Ahkâm Defterleri -1- numaralı defter: (H. 1155-1167 / M. 1742-1754), 025-1, ed. Ahmet Zeki İzgöer, Diyarbakır: Dicle Üniversitesi İlahiyat Fakültesi, 2016, s. 64.

20 Divan-ı Hümayun sicilleri Diyarbekir Ahkâm Defterleri -1- numaralı defter: (H. 1155-1167 / M. 1742-1754), 025-2, ed. Ahmet Zeki İzgöer, Diyarbakır: Dicle Üniversitesi İlahiyat Fakültesi, 2016, s. 65.

21 Sarıcık, Osmanlı İmparatorluğu’nda Nakîbü’l-Eşrâflık Müessesesi, s. 96-97.

22 Divan-ı Hümayun sicilleri Diyarbekir Ahkâm Defterleri -1- numaralı defter: (H. 1155-1167 / M. 1742-1754), 
Seyyidlerin geçimlerini sağladıkları hayvanların vergiden muaf edilmeleri için bulundukları talepleri de yerine getiriliyordu. Bu konuda Evasit-1 Muharrem 1160 / 23 Ocak-1 Şubat 1747 tarihinde Diyarbakır valisine ve mollasına gönderilen bir emirde, şehrinizde ikamet eden Şeyh Ahmed-i Kasri evlatlarından Seyyid İsmail ve Seyyid Mehmed'in sâdâd-ı kiramdan olduklarına dair ellerinde hüccet-i şeriyyeleri mevcut olduğundan geçimleri için besledikleri yüz ellişer koyundan vergi alınmaması ve bu konuda rahatsız edilmemeleri hususunda yetkililere emir gönderildi. ${ }^{23}$

Yine Seyyidlerin geçimlerini sağlamak için besledikleri koyunlardan vergi alınmaması hususunda Evasıtı Şaban 1160 / 18-27 Ağustos1747 tarihinde gönderilen emirde, Seyyid İbrahim ve Seyyid Osman'ın sâdâd-1 kiramdan oldukları ve hücceti şerife sahip olduklarından maişetleri için besledikleri yüz altmışar vergi alınmaması hususunda voyvodaya talimat verilmesi için emir gönderildi. ${ }^{24}$

Sipahilerden bazılarının da Seyyidlerin tasarruf ettikleri yerlerden fazladan vergi talep etmeleri de olmuştur. Bu hususta gönderilen Evaili Muharrem 1161/ 3-12 Ocak 1748 tarihinde gönderilen emirde, Harput'un tımar köylerinden Zaluni köyünün mutasarrıfı olan Seyyid Mustafảnın tahıl ve pamukta ödemesi gereken vergiyi ödediği halde, sipahilerin "dört kileden bir şahne olur mu? " diyerek fazla vergi talebinde bulunmuşlardır. Kayıt ve kanun dışı davranışları aşikâr olan bu şahısların kanun üzere hareket etmelerinin bildirilmesi, görevlerinin de zaman zaman gelir karşıllğ̆1 vergi rayicini beğenmeyip kafalarına göre artırdıkları da olmuştur. ${ }^{25}$

İmam ve hatiplerin vergiden muaf olduklarına dair Evahir-i Recep 1162/ 6-15 Temmuz 1749 tarihinde gönderilen emirde, Mardin kazasının Kara Dere köyü camisinde imam-hatip olan Halil Halife görevin ifa etmekte kusuru olmadığı ve vergiden muaf olduğu halde köy zabiti tarafından rüsum-1 ra’iyyet talebinde bulunulduğu beyan etmiştir. İmamlar hutbe ve namazda kendilerine uyulan insanlar olduğundan rüsum-i råiyyet ve tüm vergilerden muaf oldukları önemle vurgulanarak buyruldu. ${ }^{26}$

Seyyidlerin geçimleri için besledikleri koyunlardan vergi alınmaması hususuyla ilgili olarak Evahiri Ramazan 1162/ 3-12 Eylül 1749 tarihinde gönderilen emirde, Mardin kazası halkından olan Seyyid Mehmed, Seyyid Ali ve diğer üç Seyyid'den maişetleri için besledikleri yüz ellişer koyundan tahsildarların kanuna mugayir vergi talep ettikleri bildirilmiştir. Vergiden muaf oldukları halde tahsildarların tamamından vergi almaya kalkmaları kanuna uygun olmadığı ve kanun üzere hareket edilmesi için emri şerif gönderildi. ${ }^{27}$

025-3, ed. Ahmet Zeki İzgöer, Diyarbakır: Dicle Üniversitesi İlahiyat Fakültesi, 2016, s. 65.

23 Divan-ı Hümayun sicilleri Diyarbekir Ahkâm Defterleri -1- numaralı defter: (H. 1155-1167 / M. 1742-1754), 104-2, ed. Ahmet Zeki İzgöer, Diyarbakır: Dicle Üniversitesi İlahiyat Fakültesi, 2016, s. 269.

24 Divan-ı Hümayun sicilleri Diyarbekir Ahkâm Defterleri -1- numaralı defter: (H. 1155-1167 / M. 1742-1754), 122-4, ed. Ahmet Zeki İzgöer, Diyarbakır: Dicle Üniversitesi İlahiyat Fakültesi, 2016, s.314.

25 Divan-ı Hümayun sicilleri Diyarbekir Ahkâm Defterleri -1- numaralı defter: (H. 1155-1167 / M. 1742-1754), 129-3, ed. Ahmet Zeki İzgöer, Diyarbakır: Dicle Üniversitesi İlahiyat Fakültesi, 2016, s. 332.

26 Divan-ı Hümayun sicilleri Diyarbekir Ahkâm Defterleri -1- numaralı defter: (H. 1155-1167 / M. 1742-1754), 162-4,ed. Ahmet Zeki İzgöer, Diyarbakır: Dicle Üniversitesi İlahiyat Fakültesi, 2016, s.421.

27 Divan-ı Hümayun sicilleri Diyarbekir Ahkâm Defterleri -1- numaralı defter: (H. 1155-1167 / M. 1742-1754), 166-1, ed. Ahmet Zeki İzgöer, Diyarbakır: Dicle Üniversitesi İlahiyat Fakültesi, 2016, s.427. 
Musul kazasında Naim aşiretinden Seyyid Gaybi, Seyyid Abdullah ve diğer seyyidlerin vergi vermemeleri hususunda ilgililere gönderilen Evahiri Muharrem 1163/ 30 Aralık 1749-8 Ocak 1750 tarihinde hüküm gönderilmiştir. Bunların sâdâd-ı kiramdan oldukları ve hücceti şeriyyelerinin bulunduğu, Musul kazasında tasarruf ettikleri her hangi emlak ve mallarının olmadığı halde oranın halkı ve ehli örf tarafından vergi vermeye zorlandıkları belirtilerek kanuna mugayir olarak rencide edilmemeleri ve emri şerif doğrultusunda hareket edilmesi buyruldu. ${ }^{28}$

\section{Vergilerini Ödedikleri Halde Fazla Vergi Tahsilinde Bulunulan Yerleşim Birimleri}

Osmanlı devleti, her türlü feodal bağlılıkları kaldırarak yerel askeri idari otoritelerin faaliyetlerini ve reayadan alacakları şeyleri kanun ve nizama bağlıyor, durumu yapılan tahrir ve kayıtlara sıkı sıkıya bağımlı kalarak yürütüyordu. Bunun sonucu olarak Padişahı̉ın icra yetkisini taşıyan baştan beylerbeyi, sancak beyleri, diğer taraftan kanun ve nizamların kontrol görevi verilen kadılar, birbirlerini karşılıklı denetler ve bunun için merkezle doğrudan doğruya yazışma halinde bulunurlardı. Devletin en önemli görevi, reayayı yerel otorite sahiplerinin yolsuzluklarından korumaktı. Bu kadar sıkı tedbirlere rağmen her dönemde, otorite sahiplerinin yolsuzluklarından bahsedilmiştir. $^{29}$

Osmanlı devleti reaya kanunnamesinin ilk üç faslı, ceza maddelerini ihtiva eder. Ceza kanunları Hıristiyan-Müslüman tebaa için ortaktır. Fasıllar birincisi Müslüman reayaya, ikincisi yürüklere, üçüncüsü Hıristiyan reayaya olmak üzere üç kısımdan oluşur. Müslüman ve Hıristiyan reayaya ait kısımlar, reaya ile tımarlı sipahi arasındaki vergi ilişkilerini düzenleyen kuralları kapsar. Bunun sonucu olarak Osmanlı raiyyet-rüsumunun sadece bir vergi sisteminden ibaret olmadığı, aynı zamanda devlet içinde sınıfların statüsünü tespit eden bir sistem de olduğu görülmektedir. ${ }^{30}$

XVIII. yüzyılda merkezi otoritenin zayıflanması sonucu, yerel güçlere vergi ve güvenlik işlerinde yetkiler tanınmıştır. Anadolu'da Celallilere karşı valilerin ve diğer görevlilerin ücretli sekban askeri besleme zorunluluğu dolaysıyla reayadan aidat toplamaları, yani tekâlif-i Şâkka yeni dönemde yaygınlaşan bir yöntemdi. Bu duruma özellikle her birime toptan belirlenen Avarız-1 Divaniye vergisinin halk arasında herkesin durumuna göre dağıtma ve toplama görevi, yerel kadı başkanlığında o kazanın ayan ve eşrafına verilmesi düzenleyici rol oynayan kadıların nüfuz ve yetkileri gittikçe yerel ayanın elinde toplanmaya başlandı. Bu durum haksız vergilerin talep edilmesine ve köylünün durumuna bakılmaksızın vergiye ortak kılınmaya çalışılarak birçok huzursuzlukların çıkmasına neden olmuştur. ${ }^{31}$

Köylü ve sipahi ilişkilerine baktığımızda, sipahinin başlıca sorumluluğu çift-hane

28 Divan-ı Hümayun sicilleri Diyarbekir Ahkâm Defterleri -1- numaralı defter: (H. 1155-1167 / M. 1742-1754), 173-1, ed. Ahmet Zeki İzgöer, Diyarbakır: Dicle Üniversitesi İlahiyat Fakültesi, 2016, s.444.

29 Halil İnalcık, Devleti Aliyye Osmanlı İmparatorluğu Üzerine Araştırmalar-I, İstanbul: Türkiye İş Bankası Kültür Yayınlar1, 2011, s.320.

30 İnalcık, Osmanl İmparatorluğu Toplum ve Ekonomi, s.31-32.

31 İnalcık, Devleti Aliyye Osmanlı İmparatorluğu Üzerine Araştırmalar-I, s.333-337. 
sistemini korumaya yönelik kanunları uygulamak ve devamlı kontrolünü sağlamaktır. Toprakların bölüşülmesine asla izin verilmez. Toprak olarak varisler arasında paylaşılan, yalnız bağ ve bahçelerdir. Köylü ile sipahiler arasında çatışma konusu olan angaryaların dışında sipahinin, reayayı kanunda belirlenen miktar dışında para ve fazla vergi almaya çalışmasıydı. ${ }^{32}$

Kulp kazasının Boşat nahiyesine bağlı Malos ve Boşat köyleri halkı kendilerine ait imdad-ı hazeriye ve seferiye vergisini ödediklerinden Mefarikin kazası halkının kendi vergilerini kanun dışı baskı ve zor kullanarak bu köylerin üzerine yükledikleri bildirilmişti. Evahiri Cemaziyülahır 1155/ 4-13 Ağustos 1742 tarihinde Diyarbakır Valisi ve ilgili kadılara gönderilen hükümde; Mefarikin kazası halkının zor ve baskı sonucu kendi vergilerini de bu köylere ödettikleri, duruma el konularak Divanı Hümayunda bulunan defterlere göre işlem yapılması emredilmişti. Bu defterlere göre Diyarbakır eyaletine bağlı kazalarda, sefersiz senelerde hazeriye, saferlerin olduğu senelerde ise kırk dört bin kuruş seferiye vergisi konulmuştu. Sefersiz senelerinde imdad-1 hazeriyelerini ödedikten sonra halktan fazladan vergi alınmaması ve rencide edilmemelerine azami dikkat gösterilmesinin buyrulması yapılan iş ve işlemlerin belirlenmiş esas ve usullere göre yapıldığını, hiçbir zümrenin bir diğer zümreye yükünün yüklenmesine fırsat verilmemiştir. ${ }^{33}$

Bazı devlet görevlilerinin kanun dışı Çüngüş kazası köylülerinden vergi talep etmeleri üzerine yapılan şikâyet sonucu, Evahiri Cemaziyülahır 1155/ 4-13 Ağustos 1742 tarihinde Diyarbakır Valisine ve Çüngüş kadısına gönderilen emirde; adı geçen kaza halkının vergilerini zamanında ödedikleri halde Ergani maden eminin halktan bedava bal, üzüm, soğan, koyun, keçi vs. aldığı iddiaları üzerine yapılan araştırma sonucu vergi dişındaki kanuna mugayir bu tür angaryalar çok sert bir dille ortadan kaldırılmıştı. Devlet görevlilerin yetkilerini aşmamaları hususunda ciddi bir takibe tabi tutulduklarını göstermesi bakımında önemlidir. ${ }^{34}$

Devlet rüşvet suiistimalleri önlemek için çıkartılan kısıtlayıcı yönetmelikler, ya bu tür kişisel ödemeler için bir tarife saptırıyor, ya da bunları kamu gelirine dönüştürüp her türlü kişisel ücreti yasaklıyordu. ${ }^{35}$ Devlet görevlilerinden Subaşı Mustafa Ağa’nın vergi dışında haksız kazanç elde etmek amacıyla şantaj sonucu halktan menfaat temin ettiklerine dair gönderilen emir gönderilmiştir. Emirde adı geçen subaşının Çüngüş kazasının Hindibaba köyünden Mehmet oğlu Mustafa’yı ilgisi olmadığı bir öldürülme olayı ile suçlayarak dört yüz kuruş rüşvet aldığı iddiasının araştırılarak kanun üzere işlem yapılmasını, haksız yere alınan paranın kişiye iade edilmesinin bildirilmesi bu konuda devletin hassasiyetini göstermektedir. ${ }^{36}$

32 İnalcık, Osmanlı Imparatorluğu Toplum ve Ekonomi, s.13-14.

33 Divan-ı Hümayun sicilleri Diyarbekir Ahkâm Defterleri -1- numaralı defter: (H. 1155-1167 / M. 1742-1754), 006-1, ed. Ahmet Zeki İzgöer, Diyarbakır: Dicle Üniversitesi İlahiyat Fakültesi, 2016, s.14.

34 Divan-ı Hümayun sicilleri Diyarbekir Ahkâm Defterleri -1- numaralı defter: (H. 1155-1167 / M. 1742-1754), 006-2, ed. Ahmet Zeki İzgöer, Diyarbakır: Dicle Üniversitesi İlahiyat Fakültesi, 2016, s.15.

35 Halil İnalcık, Osmanlı İmparatorluğunun Ekonomik ve Sosyal Tarihi, 1. cilt, İstanbul: Eren Yayınları, 2004, s. 114.

36 Divan-ı Hümayun sicilleri Diyarbekir Ahkâm Defterleri -1- numaralı defter: (H. 1155-1167 / M. 1742-1754), 006-3, ed. Ahmet Zeki İzgöer Diyarbakır: Dicle Üniversitesi İlahiyat Fakültesi, 2016, s. 15. 
Ödemeleri gereken vergilerini ödemiş olmalarına rağmen zaman zaman başkalarının ödemesi gereken vergilerin kendilerinden talep edilmesi üzerine şikâyetlerde bulunulmuştur. Bunun üzerine Evasit-1 Recep 1155 / 11-20 Eylül 1742 tarihinde ilgililere gönderilen hükümde, Mardin kazasının Yılancık nahiyesine bağlı ve Padişah’in Halil'i ve diğer bazı köylerdeki Yarenli ve Şarkiyan cemaatleri halkından bazıları ödemeleri gereken öşürlerini ve rüsum-i raiyyetlerini defterdeki kayıtlardaki miktara göre zabitlere ödemişlerdir. Ancak yetkililerin bu köylerden başka yerlere göç edenlerin vergilerini de bu köylerin sakinlerinden haksız olarak talep etmeleri üzerine gönderilen emirde kanun ve defterdeki kayıtların dışında vergi tahsilinde bulunulmaması hususunun bildirilmesi verginin şahsi özelliğine riayet edildiğini göstermesi açısında önemli olmuştur. ${ }^{37}$

Ehli örf tarafından mükerrer şekilde vergi tahsilatının yapılmağa çalışıldığı zamanlarda olmuştur. Bununla ilgili olarak Evahir-i Recep1155/ 20-29 Eylül tarihinde ilgililere gönderilen emirde, Ergani kazasına bağlı Babacık ve diğer bazı köylerdeki halkın kanun ve defter kayıtlarına ödenmesi gereken vergilerini ödedikleri halde mükerrer ve haksız bir şekilde tekrar istenmiştir. Bu tahsilatta bulunan Ergani maden emini ve diğer ehli örf mensuplarına kanun ve kayıtların dışına çıkılmaması emir edilmiştir. ${ }^{38}$

Bazı şahısların devlet görevlileri adına da vergi tahsil yoluna gittiklerine dair gönderilen Evail-i Zilkade 1155/ 29 Aralık 1742-8 Ocak 1743 tarihli hükümde; Siverek kazasına bağlı Oşun, Millili Sarayı nahiyelerine köylerin vergilerini eksiksiz ve zamanında ödedikleri halde Siverek kazasında bazı kötü niyetli şahısların Kaza Voyvoda’sının da adını kullanarak vergi toplamaya çalışmaları üzerine durumun ortadan kaldırılması için yetkililer uyarılarak gerekli tedbirlerin alınması bildirilmişti. Devamlı suiistimal edilmeğe müsait olan vergi husussusundaki tatbik ve takibine azami dikkat edildiği görülmektedir. ${ }^{39}$

Yine bu şahıslar bu kez farklı bir metotla Voyvoda’nın adını kullanarak kanunsuz bir şekilde vergi talebinde bulunmaları üzerine Evaili Z. 1155/ / 29 Aralık 1742-8 Ocak 1743 tarihinde hüküm gönderilmiştir. Bu hükümde, bu şahısların tekrar Mehmet Ağa’nın adını kullanarak ve aslı astarı olmayan bir iddia ile üst makamlara yüklü miktarda hediyeler verildiğini ve bunun karşıllğ̆ olan akçenin salma yoluyla halktan toplanmasının emredildiğini söyleyip halkın ödedikleri verginin iki-üç katını da bu yolla halktan topladıkları tespit edilmiştir. Bunlardan vergileri dışında alınan miktarın kendilerine iadesi ve sorumluları hakkında kanun üzere acilen işlem yapılması hususunda emir verilerek bu tür olayların bir daha cereyan edilmemesi için önlem alınmaya çalışılmıştır. ${ }^{40}$

37 Divan-ı Hümayun sicilleri Diyarbekir Ahkâm Defterleri -1- numaralı defter: (H. 1155-1167 / M. 1742-1754), 007-5, ed. Ahmet Zeki İzgöer Diyarbakır: Dicle Üniversitesi İlahiyat Fakültesi, 2016, s. 18.

38 Divan-ı Hümayun sicilleri Diyarbekir Ahkâm Defterleri -1- numaralı defter: (H. 1155-1167 / M. 1742-1754), 008-2, ed. Ahmet Zeki İzgöer Diyarbakır: Dicle Üniversitesi İlahiyat Fakültesi, 2016, s. 20.

39Divan-ı Hümayun sicilleri Diyarbekir Ahkâm Defterleri -1- numaralı defter: (H. 1155-1167 / M. 1742-1754), 015-2, ed. Ahmet Zeki İzgöer, Diyarbakır: Dicle Üniversitesi İlahiyat Fakültesi, 2016, s.38.

40 Divan-ı Hümayun sicilleri Diyarbekir Ahkâm Defterleri -1- numaralı defter: (H. 1155-1167 / M. 1742-1754), 017-1, ed. Ahmet Zeki İzgöer, Diyarbakır: Dicle Üniversitesi İlahiyat Fakültesi, 2016, s.43. 
Bu kez Voyvoda’nın vekili Molla Ömer hakkında gönderilen aynı tarihli başka bir hükümde de, tahsilat esnasında asıl deftere göre değil de kendisinin 1142 yılından beri hazırlayıp ve uyguladı̆̆ı mükerrer deftere göre halktan fazladan para tahsil edildiği tespit edilmiştir. Bu paranın hak sahiplerine acilen iade edilmesi ve adı geçen kişi hakkında da gerekli işlemin yapılmasını bildirildi. Halk ile yöneticiler arasındaki iletişim kanallarının işlemesi sonucu gecikse de bu tür usulsüzlüklerin ortaya çıkmasinda etkili oluyordu. ${ }^{41}$

Yerel ayana yükselme fırsatı veren mültezimlik, köylüleri ve zanaatkârları genellikle büyük zarara uğratıyordu. ${ }^{42}$ Mültezimlerin köylülerden vergileri dışında para istemelerinin önlenmesi hususunda Evasıtı Rebiyülevvel 1156/ 5-14 Mayıs 1743 tarihinde gönderilen emirde, Harput'un Uluabad nahiyesine bağlı Vartetil köyü halkının ödemeleri gereken vergilerinin tamamını mültezimlerine ödedikleri halde, başka adlar altında ve defterlerde yazılı olmayan tarlarda dökülen başakları bin bir zahmetle toplayan köylülerden bunlar için de otuzar kırkar akçe talep etmiştir. Yapılan araştırma sonucu Defterhane-i Amire de bulunan deftere göre köyde bulunan yüz yirmi dört neferin yazılı olduğu ve ödemekle yükümlü oldukları toplam verginin ise yüz yirmi dokuz bin yüz atmış akçe olduğu yazılıdır. Kanun ve defter kayıtlarına göre işlem yapılması emir edildi. ${ }^{43}$

Zabitlerin de sürekli olarak halktan fazladan aldığı olmuştur. Bu hususta yapılan şikâyetler sonucu gönderilen Evasıtı Muharrem 1161/ 12-21 Ocak 1748 tarihinde gönderilen emirde, Palu zabitlerinin halktan 1150 senesinden beri kanuna mugayir olarak defterde yazılı olan vergiden fazla vergi aldıklarından başka her birinden yirmişer akçada zorla tahsil ettikleri bildirilmiştir. Konunun mübaşir marifetiyle araştırılması, fazladan alınan verginin hak sahiplerine iade edilmesi ve zabitler hakkında da kanun üzere işlem yapılmasının emredilmesi, devletin bu konudaki hassasiyetini ortaya koymaktadır. ${ }^{44}$

Ayanlık iddiasında bulunan kimselerinin de vergi konusunda halkı rahatsız ettikleri de oluyordu. Bu konuda yapılan şikâyetler sonucu Evahir Zilkade. 1161/ 11-20 Kasım 1748 tarihinde gönderilen bir emirde, Hale kasabasında emlak ve arazileri olmayan kişilerden hane-i Avarız-1 Divaniye vergisini ödemeleri konusunda bazı ayanlar tarafından baskı yapıp rencide etmektedirler. Bunların böyle bir hakları olmadığını kanun üzere işlem yapılması önemle belirtildi. ${ }^{45}$

Defterlerde ve kayıtlarda yazılı olmayan kalemlerden de halktan vergi tahsil etme yoluna giden sipahiler oluyordu. Bu tür şikâyetler üzerine Evaili Recep 1164/27 Ma-

41Divan-ı Hümayun sicilleri Diyarbekir Ahkâm Defterleri -1- numaralı defter: (H. 1155-1167 / M. 1742-1754), 017-2, ed. Ahmet Zeki İzgöer, Diyarbakır: Dicle Üniversitesi İlahiyat Fakültesi, 2016, s.2.

42 Suraiya Faroqhi, "Siyaset ve Ekonomi Arasındaki Yönetici Seçkinler”, Haz. Halil İnalcık ve Donalt Quarteat, Osmanlı İmparatorluğunun Ekonomik ve Sosyal Tarihi, 2. cilt, İstanbul: Eren Yayınları, 2006, s.641.

43 Divan-ı Hümayun sicilleri Diyarbekir Ahkâm Defterleri -1- numaralı defter: (H. 1155-1167 / M. 1742-1754), 028-2, ed. Ahmet Zeki İzgöer, Diyarbakır: Dicle Üniversitesi İlahiyat Fakültesi, 2016, s. 73.

44 Divan-ı Hümayun sicilleri Diyarbekir Ahkâm Defterleri -1- numaralı defter: (H. 1155-1167 / M. 1742-1754), 130-1, ed. Ahmet Zeki İzgöer, Diyarbakır: Dicle Üniversitesi İlahiyat Fakültesi, 2016, s.333.

45 Divan-ı Hümayun sicilleri Diyarbekir Ahkâm Defterleri -1- numaralı defter: (H. 1155-1167 / M. 1742-1754), 151-1, ed. Ahmet Zeki İzgöer, Diyarbakır: Dicle Üniversitesi İlahiyat Fakültesi, 2016, s.390. 
yıs-5 Haziran 1751 tarihinde ilgililere gönderilen emirde, Diyarbakırın Şark-1 Amid nahiyesine bağlı Sinanlı mezrası halkının vermekle yükümlü oldukları aşarı şer’iyle ve defterlerde yazılı tüm vergilerini ödedikleri halde ödemekle yükümlü olmadıkları ağnam vergisinin tahsiline çalışılarak rencide edildiklerini bildirmelerdir. Sipahinin bu konuda kanuna göre davranıp halkı ağnam vergisi konusunda rencide etmemesi buyruldu. ${ }^{46}$

Kadılar kendilerinin sorumluluklarının altında olan köyler de naiplerin vasıtasıyla da vergileri toplamağa çalışmışlardır. Bu görevi ifa etmek için kalabalık gruplarla köylere çıkmaları halkı rahatsız ettiği gibi, askeri zaferler sırasında yol güzergâhında bulunan yerleşim birimlerinde ki halkın rahatsızlı̆̆ına sebep oluyorlardı. ${ }^{47}$ Yolların kenarında veya geçiş noktalarında bulunan köylerin ücretsiz ve zorla yiyeceklerine el konularak vergi alınmaya çalışıldığı da oluyordu. Bu konuda ilgililer evaili Şaban 1166/ 4-13 Haziran 1753 tarihinde sert bir dille uyarılarak emri şerif gönderilmiştir. Bu emirde, Ergani Madeni'nin Uslu mezrası halkı yol üzerinde olduklarından gelen geçenlerin zorla yiyeceklerini aldıkları, her hangi bir ücret ödemedikleri, bazı görevlilerinde bunu vergi olarak tahsil etmeğe çalıştığ 1 ve halkın zor durumda olduğu bildirilmiştir. Bundan böyle bu ücret mukabili dışında yiyecek alınmaması ve halkın rahatsız edilmemesi için daha önceden gönderilen emri şerif doğrultusunda hareket edilmesi buyrularak herkesin bu konuda dikkat ve ihtimam göstermesi emir edildi. ${ }^{48}$

Devlet orduların ikmali sırasında disiplin sorunlarını ve halkın şikâyetlerini asgari duruma indirgemek için orduların kentlere girmesine nadiren izin verilirdi. Orduya birçok zanaatkâr eşlik eder ve konakladığı sırada bunlarda atölyelerini kurar ve işlerini yaparlard $\mathbf{1}^{49}$. Buna rağmen şikâyetler tamamen önlenememiştir. Yol kenarında bulunan ve askerlerin geçiş noktasında olan köylerin ödedikleri vergilerin çokluğundan dolayı yapılan şikâyetler üzerine Evaili Şaban 1166/ 4-13 Haziran 1753 emir gönderildi. Diyarbakır’n Çüngüş kazasının Ebutahir nahiyesinin Uslu köyünün seferlere gidip gelen askerlerin geçiş güzergahında olması ve ödenen vergilerin çokluğundan dolayı köyün boşaldığ eden kırk altı kuruş on beş akçe vergisinin af edilmesi, her hane için senede kırkar kuruş salyanelerinden dört buçuk haneye isabet eden yüz seksen kuruşun bir defa Çüngüş mahkemesinin huzurunda teslim edildikten sonra vilayet harcı, salyane ve vergi talep edilmemesi ve bunun kayttlara geçirilmesi emir edilmesi devletin her yeri yaşanır halde tutmasına verdiği önem açısından da önemlidir. ${ }^{50}$

\section{Vergilerini Ödedikleri Halde Fazla Vergi Talebinde Bulunulan Şahıslar}

Osmanlı Devletinde ferman- kanunlar, çoğu kez bir gruba ya da bir göreve ait emir-

46 Divan-ı Hümayun sicilleri Diyarbekir Ahkâm Defterleri -1- numaralı defter: (H. 1155-1167 / M. 1742-1754), 210-2, ed. Ahmet Zeki İzgöer, Diyarbakır: Dicle Üniversitesi İlahiyat Fakültesi, 2016, s.545.

47 İnalcık, Devleti Aliyye Osmanlı İmparatorluğu Üzerine Araştırmalar-I, s.327-328..

48Divan-ı Hümayun sicilleri Diyarbekir Ahkâm Defterleri -1- numaralı defter: (H. 1155-1167 / M. 1742-1754),

253-1, ed. Ahmet Zeki İzgöer, Diyarbakır: Dicle Üniversitesi İlahiyat Fakültesi, 2016, s. 647.

49 İnalcık, Osmanl İmparatorluğu Toplum ve Ekonomi, s.597

50 Divan-ı Hümayun sicilleri Diyarbekir Ahkâm Defterleri -1- numaralı defter: (H. 1155-1167 / M. 1742-1754), ed.

Ahmet Zeki İzgöer Diyarbakır: Dicle Üniversitesi İlahiyat Fakültesi, 2016, 253-2 s. 648. 
lerden oluşur. Buda hukukun şahsiliği prensibi, vergi kanunlarının bölge veya gruba özel niteliği söz konusudur. Bu hükümler belirtilen şahısları ilgilendirdiği gibi, bir görevliye uygulanacak hususları da bildirerek üçüncü şahısları da bağlayan hükümler içerebilir. Burada ki esas amaç genellikle eskiden beri yerleşmiş olan örf ve adetlerin onaylanmasını yahut onların başka bir bölgeye uygulanmasını emreder. ${ }^{51}$

Bu gruplardan yürüklerin göçer olmaları nedeniyle olumsuz etmenlere açık olduklarından yerleşik nüfusa göre daha kolay etkilenmeleri söz konusu olduğundan ekonomik yönden olumsuz etkileniyordular. Bu şartlarda ya eşkiyalaşıyor ya da küçük ücret karşılığında imparatorluk ordusuna paralı asker yazılıyorlardı. Otlakçılık ekonomisinin hâkim olduğu Doğu Anadolu’da göstermelik vergiler kendi beyleri tarafından toplanıp devlete teslim ediliyordu. Böylece irsi reislerinin emri altında askeri hizmet vermeleri sağlaniyordu. ${ }^{52}$

Mardin kasabasındaki mahallelerde ikamet eden yedi Yahudi marangoz, emlak ve yerleri olmadığından, avarız ve benzeri vergileri verecek gelirleri de bulunmadığ için Avarız-1 Divaniye vb. vergilerden muaf bulunmaları hususunda müracaatta bulunmuşlardı. Yapılan araştırmalar sonucunda, emlak vb. tasarruf etmedikleri ve bunlara musallat olan bezzaz taifesindeki bazı kişilerin de kendileriyle aynı vergiyi vermeleri hususunda kanuna mugayir baskı yapıldığı tespit edilmişti. Evaili Recep 1155 / 2-11 Eylül 1742 tarihinde gönderilen emirde ilgili defterlerin tetkikinde bu şahısların bu vergilerden muaf oldukları belirtilmiştir. Bunlara ilgili taifenin haksız olarak kendileriyle aynı vergilere ortak kılındıkları nedeniyle bu durumun önlenmesini ve adı geçen marangozların rencide edilmemeleri, kanun üzere hareket edilmesi kesin bir dille bildirilmesi Osmanlı Devleti’nin inanç ve ırk ayırımı yapmadan hukukun üstünlüğü ilkesini uygulamasında taviz vermediğini ortaya koymuştur. ${ }^{53}$

Osmanlı Devletinde belirli görevleri yerine getiren görevliler, bazı vergilerden muaf tutulmuşlardır. Muaf olan bazı görevlilerden vergi alınması üzerine yapılan şikâyetlerle ilgili kadıya Evaili Recep 1155 /2-11 Eylül 1742 tarihinde emir gönderilmiştir. $\mathrm{Bu}$ emirde, Amid mahallesi sakinlerinden zimmi Esmah İsa Nasriye Camisinin Seray darı (yemek ve sofra işlerine bakan görevli) olduğundan dolayı Avarı-ı Divaniye ve seferiye vergilerinden muaf olduğu belirtilmiştir. Buna rağmen ehli örf tarafından vergi ödenmesi talep edilmesinin kanuna mugayir olduğundan bu kişinin rencide edilmemesi ve kanuna göre hareket edilmesinin bildirilmesi kişi hak ve sorumluluklarına gösterilen hassasiyet açısından önemlidir. ${ }^{54}$

Köylerde bilfiil tarımla uğraşan yeniçerilerin olduğu 1549 tarihli fermandan anlaşılmaktadır. Askeriler için vergilendirmede özel bir muamele söz konusu olmamakla birlikte kanunlar, sultanın kapıkulları için bazı kişisel muafiyetler öngörüyordu. Mesela köylülerin ödedikleri boyunduruk resminden muaf oldukları gibi, sipahilerin

51 İnalcık, Devleti Aliyye Osmanlı İmparatorluğu Üzerine Araştırmalar-I, s.238.

52 İnalcık, Osmanl İmparatorluğunun Ekonomik ve Sosyal Tarihi, 1. cilt, s.79-80.

53 Divan-ı Hümayun sicilleri Diyarbekir Ahkâm Defterleri -1- numaralı defter: (H. 1155-1167 / M. 1742-1754), 005-6, ed. Ahmet Zeki İzgöer, Diyarbakır: Dicle Üniversitesi İlahiyat Fakültesi, 2016, s.14.

54 Divan-ı Hümayun sicilleri Diyarbekir Ahkâm Defterleri -1- numaralı defter: (H. 1155-1167 / M. 1742-1754), 006-5, ed. Ahmet Zeki İzgöer, Diyarbakır: Dicle Üniversitesi İlahiyat Fakültesi, 2016, s.16. 
ürünlerini ambarlarına taşımaktan da yükümlü tutulmamışlard $1 .{ }^{55} \mathrm{Bu}$ şahıslardan da fazladan vergi talep edilmesi sonucu yapılan başvuruların aynı titizlikle takip edildiğine dair Evahiri Şaban 1155/ 20-29 Ekim 1742 tarihindeki hükümde: Sad kasabası sakinlerinden yeniçeri Hacı Recep Beşe b. Mahmut'un ödemekle yükümlü olduğu vergileri eksiksiz ve zamanında ödenmesine rağmen kendisinden kanuna mugayir vergi talep edilmiştir. Bu durumda kişinin rencide edilmeyerek kanun üzere hareket edilmesinin hatırlatılması da gösteriyor ki sadece vatandaştan tek değil belirli görevleri ifa eden devlet görevlilerinden da fazla vergi aldıkları görülmüşsür. ${ }^{56}$

Toptan satılmak üzere kent pazarına getirilen mallardan, bac denilen çarşı-Pazar resimleri alınırdı. Pazar baçlarının oranı düşük tutulurdu. Kırkta bir oranında alınan İslam mal varlığı vergisi zekât) temelinde takdir ediliyordu. ${ }^{57}$ Tüccarlardan da defterlerde yazılı kayıtların dışında fazla vergi talep edildiği de olmuştur. Bu konuda Evahiri Rebiyülevvel 1156/ 14-23 Mayıs 1743 tarihinde gönderilen emirde, Diyarbakır'da ikamet eden ve ticaretle uğraşan Molla Bekir ve iki arkadaşı taşradan Diyarbakır’a mal getirmektedirler. Bunlar kanun ve defter kayıtlarına göre ödemeleri gereken on altı bin üç yüz altmışaltı akçe bac vergilerinin tamamını eksiksiz ödedikleri halde zabit defter ve kayıtlara itibar etmeyerek fazladan vergi talep ederek rencide edilmeleri üzerine acilen kayıtlara göre hareket edilmesi emir edildi. ${ }^{58}$

Belli başlı görevleri ifa eden görevlilerden bazı vergilerin alınmaması da defter kayıtlarında yer almıştır. Bu konuda da gönderilen Evaili Muharrem 1157 / 16-25 Şubat 1744 tarihli emirde, Çemişgezek'in Sisne nahiyesine bağlı Sudak köyünde vefat eden Abdülgani Mehmed'in evladı Hasan yol üzerinde gelip gidenlere hizmet ettiğinden baş vergisi ve Avarı-1 Divaniyedan muaf olduğu halde kendisinden bu vergilerin tahsili istenmiştir. Talebi üzerine yapılan kayıtların tetkikinde "baş akçesi ile Avarız-1 Divaniyeı-1 divaniyeden emin ola” şeklindeki kayıtla ilgilinin bu vergilerden muaf olduğu sonucuna varılmıştır. Bu kayda göre işlem yapılması bildirildi. ${ }^{59}$

Vilayette mehter takımında görevli olanlarında vergi muafiyetlerine sahip oldukları bu kayıtta anlaşılmaktadır. Bu konuda yapılan başvuruda vergilerini eksiz ödedikleri halde buna itibar etmeyip fazladan ödeme yapmağa zorlanan şahıslarla ilgili olarak Evasıtı Cemaziyülahır 1157/ 22 Temmuz-1 Ağustos 1744 tarihinde Diyarbakır kad1sına gönderilen emirde, Ekrâd taifesinden Şehriban Saliha hatun kendisinin ihtiyar olduğunu, oğlununda Vali’nin Mehter hanlığında görev ifa etmektedir. Kendisinin ödemesi gereken vergileri kusursuz ödediği halde fazladan vergi talep edilmiştir. Yapılan araştırmada ehli örf tarafından fazladan vergi tahsil yoluna gidilerek rencide edildiği, kayıtlar uyulmadığı tespit edildiğinden kanun üzere hareket edilmesi emir

55 İnalcık, Osmanlı İmparatorluğunun Ekonomik ve Sosyal Tarihi, 1. cilt, s. 221.

56 Divan-ı Hümayun sicilleri Diyarbekir Ahkâm Defterleri -1- numaralı defter: (H. 1155-1167 / M. 1742-1754), 011-5 ed. Ahmet Zeki İzgöer, Diyarbakır: Dicle Üniversitesi İlahiyat Fakültesi, 2016, s.30.

57 İnalcık, Osmanl İmparatorluğunun Ekonomik ve Sosyal Tarihi, 1. cilt, s.254-255.

58 Divan-ı Hümayun sicilleri Diyarbekir Ahkâm Defterleri -1- numaralı defter: (H. 1155-1167 / M. 1742-1754), 028-3, ed. Ahmet Zeki İzgöer, Diyarbakır: Dicle Üniversitesi İlahiyat Fakültesi, 2016, s.74.

59 Divan-ı Hümayun sicilleri Diyarbekir Ahkâm Defterleri -1- numaralı defter: (H. 1155-1167 / M. 1742-1754), 046-2, ed. Ahmet Zeki İzgöer, Diyarbakır: Dicle Üniversitesi İlahiyat Fakültesi, 2016, s.119. 
edildi. ${ }^{60}$

Metruk yerleri ekip biçerek tarıma elverişli hale getiren reayadan kanun dışı vergi talebinden bulanan ehli örf taifesi de olmuştur. Bu konuda yapılan şikâyetler sonucu Evasıtı Rebiyülahır 1158 / 13-22 Mayıs 1745 tarihinde Musul kadısına gönderilen emirde, Musul dışında harabe olan araziyi işleyerek verimli hale getiren Mehmed b. Yahya'dan üzerine düşen vergilerini eksiksiz ödediği halde ehli örf taifesinin kanun ve kayıt dışı fazladan vergi talep ettiği tespit edilmiştir. Bu konuda kayıtlara uyulması buyrularak çalışkan insanların korunmasına çalışıldığı açıkça da görülmektedir. ${ }^{61}$

Devlet sosyal barışın sağlanması ve yerleşik hayatın teşvik edilmesi yönünden konargöçer, sağlık durumları elverişli olmayan hasta veya sakat olanlar ile çalışmaya elverişli olmayanları da bazı vergilerden muaf tutuyordu. Bu tarz şikâyetler sonucu Evahiri Safer 1159 /14-23 Mart 1746 tarihinde yapılan başvuru sonucu gönderilen emirde, Diyarbakır eyaletinde Abbas b. İbrahim'in Araban taifesinden konargöçerdi. Bunun ihtiyar ve iki elinin de yaralı olması nedeniyle çalışamadığından defterden yazılı olandan fazla vergi talep edilerek rencide edilmemesi önemle vurgulanarak kişinin korunmasına gösterilen ihtimamı göstermektedir. ${ }^{62}$

Devlet, kişilerin mağdur edilerek işlerini terk etmemeleri ve her yerin yaşanır halde tutulması konusunda da hassas davranmıştır. Ödenmesi gereken vergiler dışında voyvodalar tarafından yükümlü olmadıkları vergileri de talep edilmesi sonucu yap1lan şikâyetlerle ilgili olarak Evahiri Muharrem 1156 / 16-25 1743 tarihinde gönderilen emirde, Diyarbakır'da küçük silah imalathanesini mukataa statüsünde işleten Abdullah ve Halil'in işletme ile alakalı yükümlü oldukları vergileri ödediklerini bildirmişlerdir. Ancak Voyvoda'nın ek vergiler talep etmesi sonucu işlerini terk edip ayrılmışlardır. Bu durum kişilerin mağduriyetleriyle birlikte devleti de zarara uğratmaktadır. Baş defterdarlığın kararları doğrultusunda hareket edilerek kişilerin mağduriyetlerinin giderilmesi emredilmişti. ${ }^{63}$

Osmanlılar kendi idareleri altına giren gayrimüslimlerden, Müslümanlardan farklı olarak Cizye vergisini alırlardı. Bu vergiyi ödeyenlerin inançlarını yaşamalarına, kendi dini liderlerini seçmelerine müsaade edilirdi. ${ }^{64}$ Gayri Müslimlerden fazladan cizye vergisini tahsil etmeye çalışan cizye voyvodalarıyla ilgili Evaili Şevval 1162/ 15-24 Eylül 1749 tarihinde Diyarbakır kadısına gönderilen emirde, Diyarbakır’n iki mahallesinde ikamet eden on iki gayrimüslim vergilerini ve cizyelerini eksiksiz ödedikleri halde cizye voyvodası ve ehli örf taifesi tarafından fazla vergi alındığı şikâyet edilmiştir. Bu hususta Divanı Hümayun kaleminde bulunan ilgili defterin kenarına şerh edilen emri şerif doğrultusunda hareket edilmesi ve bu taifenin rahatsız husu-

60 Divan-ı Hümayun sicilleri Diyarbekir Ahkâm Defterleri -1- numaralı defter: (H. 1155-1167 / M. 1742-1754), 054-1, ed. Ahmet Zeki İzgöer, Diyarbakır: Dicle Üniversitesi İlahiyat Fakültesi, 2016, s. 141.

61 Divan-ı Hümayun sicilleri Diyarbekir Ahkâm Defterleri -1- numaralı defter: (H. 1155-1167 / M. 1742-1754), 068-1, ed. Ahmet Zeki İzgöer, Diyarbakır: Dicle Üniversitesi İlahiyat Fakültesi, 2016, s. 175.

62 Divan-ı Hümayun sicilleri Diyarbekir Ahkâm Defterleri -1- numaralı defter: (H. 1155-1167 / M. 1742-1754), 080-4, ed. Ahmet Zeki İzgöer, Diyarbakır: Dicle Üniversitesi İlahiyat Fakültesi, 2016, s. 210.

63 Divan-ı Hümayun sicilleri Diyarbekir Ahkâm Defterleri -1- numaralı defter: (H. 1155-1167 / M. 1742-1754), 022-1, ed. Ahmet Zeki İzgöer, Diyarbakır: Dicle Üniversitesi İlahiyat Fakültesi, 2016, s.56 .

64 Erhan Afyoncu, Sorularla Osmanlı İmparatorluğu-V, İstanbul: Yeditepe Yayınları, 2007, s. 156. 
sunda azami dikkat ve ihtimam gösterilmesi ise insanın inanç, ırk, bakımında bir ayırıma tabi tutulmadığı ve her konuda olduğu gibi kanun ve nizama göre hareket edildiği görülmektedir. ${ }^{65}$

\section{Sonuç}

Askeri ve reaya sınıf arasında ki ilişkilerin çok sağlam temellere oturtulduğu ayrıca vuku bulan şikâyetlerin titizlikle incelenerek sonuçlandiğg görülmüştür. Şikâyetlerin konularına göre tasnif edilerek ilgili birimlere bildirildiği ve her konun ilgili defter kayıtlarının esas alınarak sonuçlandırılmaya çalışıldığı görülmüştür. Vergi muafiyetine sahip zümre ve şahıslar ile görevlilerin muafiyet beratlarının kendilerine verildiği gibi ilgili defter ve dairelerinde de kaydedilmiştir. Seyyidlere Peygamber Efendimizin soyundan olmaları nedeniyle vergi muafiyetleri getirildiği, hürmet gösterildiği ve bunların İstanbul'da Nakibüleşraf dairesinde kayıtlarının tutularak Seyyid olamayanların sızmalarını önlenmiştir.

Bu şikâyetlerde görülen dava konularının daha çok sipahi ve köylü arasında geçen anlaşmazlıklara çözüm getirilerek halkın zarar görmesini engellediği gibi yerleşim birimlerindeki üretimin devam ederek sosyal-ekonomik dengenin korunması devamlı gözetilmiştir. Bütün sınıf ve zümrelere kanun ve kayıtlar doğrultusunda adalet üzere hareket edilerek reayanın mağduriyetleri giderilmeye çalışılmıştır. Bazı durumlarda vergi muafiyeti getirilen reaya, yerel beylerinin yönetiminde askerlik hizmetine alınarak asayişin ve huzurun teminine de katkı sunmuştur.

\section{Kaynakça}

Afyoncu, Erhan. Sorularla Osmanlı Imparatorluğu-V. İstanbul: Yeditepe Yayınları, 2007.

Akdağ, Mustafa. Türkiye’nin İktisadî ve İçtimâ̂ Tarihi-I. Ankara: Barış Kitap Basım Yayın Dağıtım, 1999.

Bilge, Sadık Müfit. "XV-XVIII Yüzyıllarda Osmanlı Devletinde Vergi Muafiyeti”. Osmanlı Coğrafyası Kültürel Arşiv Mirasının Yönetimi ve Tapu Arşivlerinin Rolü Uluslararası Kongresinde Sunulan Bildiri. İstanbul: 2012.

Divan-ı Hümayun sicilleri Diyarbekir Ahkâm Defterleri -1- numaralı defter: (H. 1155 1167 / M. 1742-1754). Ed. Ahmet Zeki İzgöer. Diyarbakır: Dicle Üniversitesi İlahiyat Fakültesi, 2016.

Faroqhi, Suraiya. “Siyaset ve Ekonomi Arasındaki Yönetici Seçkinler”. Haz. Halil İnalcık ve Donalt Quarteat. Osmanl Imparatorluğunun Ekonomik ve Sosyal Tarihi. 2 cilt. İstanbul: Eren Yayınları, 2006.

İnalcık, Halil. Devleti Aliyye Osmanlı İmparatorluğu Üzerine Araştırmalar-I. İstanbul: Türkiye İş Bankası Kültür Yayınları, 2011.

İnalcık, Halil. Osmanlı İmparatorluğu Toplum ve Ekonomi. İstanbul: Eren Yayınları, 1996.

65 Divan-ı Hümayun sicilleri Diyarbekir Ahkâm Defterleri -1- numaralı defter: (H. 1155-1167 / M. 1742-1754), 166-3, ed. Ahmet Zeki İzgöer, Diyarbakır: Dicle Üniversitesi İlahiyat Fakültesi, 2016, s.171. 
İnalcık, Halil. Osmanlı İmparatorluğunun Ekonomik ve Sosyal Tarihi. 2 cilt. Eren Yayınları, İstanbul: 2004.

İnalcık, Halil. Osmanlida Devlet, Hukuk, Adalet. İstanbul: Eren Yayınc1lık, 2005.

Sarıcık, Murat. Osmanlı İmparatorluğu’nda Nakîbü’l-Eşrâflık Müessesesi. İstanbul:

Türk Tarih Kurumu Yayınları, 2003.

Türkiye Diyanet Vakfi İslam Ansiklopedisi. İstanbul, 1994.

Türkiye Diyanet Vakfi İslam Ansiklopedisi. İstanbul, 2006. 
İNSAN\&İNSAN, Y11/Year 6, Say1/Issue 21, Yaz/Summer 2019, 673-690

DOI: https://doi.org/10.29224/insanveinsan.516626

\section{Tax Irregularities in Diyarbekir Province (1742-1752): Some New Findings and Analysis Between 1742 and 1752 Diyarbakır Province Case}

İBRAHIM ÖZGÜL

Abstract: This study aims to determine and reveal the irregularities occurring during the tax collection in Diyarbakir province between 1742-1754. In the study, data was obtained by examining Financial (Ahkam) Books on Diyarbakır province. Other sources regarding this subject were used as well. According to the study findings; conveying a lawsuit file for beneficiaries (public) to top authorities and administration against law enforcement, implication of the laws and faced injustices was easily possible. Furthermore, it was found that the authorities had to execute the complaints under the principles of law, justice and morality. There were regular publications and edicts including encouragements and warnings on justice issue. By registering the tax system in detail; the process and transactions were carried out in a healthy manner in this direction. It was concluded that some tax collection implications like high tax demand by officials during the tax collection were also observed.

Keywords: Diyarbakir, Ahkâm registers, Taxation, Eighteenth century. 